\title{
円筒プランジ研削における変位外乱形 強制振動の増幅現象の解析*
}

\author{
高 本 洋 祐 ${ }^{* *}$ \\ Analysis of Amplified Displacement Disturbance-type Forced Vibration
}

in Plunge-cut Cylindrical Grinding

Yousuke Koumoto

The amplification of forced vibration in plunge-cut cylindrical grinding is analyzed theoretically and experimentally. In machining works of a certain size range, the forced vibration coming from the gear pump in a specific grinding machine is found to increase gradually or rapidly after start of grinding. This paper discusses a general mechanism of the vibration amplification as experienced with the case and methods of suppression are explained. The effectivity in suppression is confirmed experimentally.

Key words: grinding, vibration, displacement diturbance-type forced vibration, forced vibration amplification, vibration suppression

\section{1. 緒言}

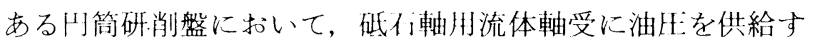
るギヤポンプの発生:する強制拔動が研削中に増大していき，許 容レベルを越えてしま5現象が観察された。高精度攸筒研削に 障害となるこの種の外乱振動の抑制は，熟練した作業者に頼る ことが多く，理論的説明が久けている。そのため一つの抑制方 法が，ある場命には有効でも他の場合には無効になる，という ように真の技術的手法に結びつかない。これ至でにも砥不の動 的アンバランスにより生:ずる強制振動（䂸不问転数に同期した

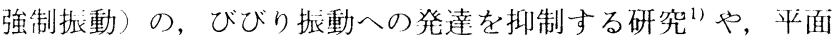
研削艋に打ける油压の脈動に起内するびびりマークをアキュム レータを使朋して抑制した例2)などは報告されているが，砥石 回転数に闹期しない強制拢動の増幅現爱およびその抑制方法を 扱った研究は見当たらないようである。本研究ではこの種の振 動增幅のしくみを，著者らが先に提案した㨫筒プランジ研削に おける，砥不问転に基づく外乱強制振動を考慮した振動の発生 機構の理論モデル を光用いて明らかにし，闹時にその振動増幅 の抑制方法を見いだすことを目的としている.そして外乱振動 の影響が観察できる状況で理論的説明ができ，またそれに基づ いた抑制方法の効果が確認できたので報告する.

\section{2. 実験の方 法}

図 1 に串験装置の概略を示す.円筒研削盤を用い, 図 2 に示 寸種々の形状の工作物の両端を固定センタで支持し, 円筒プラ ンジ研削する。

図 1 に見るように，心押台側固定センタに取り付けた加速度 ピックアップによって研削中の切込み方向の振動を，また砥石 軸端の V プーリに固定した無接点スイッチで砥石回転数を検 出し，それぞれデータレコーダに記録し，加速度信号はFFT 解析器で周波数分析を行う. 砥石回転数は, 周波数カウンタで 常時監視し, 速度レギュレータの譈調整を行って, 設定した回 転数を維持するよらに補正した。

工作機械：豊田工機製万能研削盤（RU 28-50）

* 原稿受付 平成 5 年 8 月 $16 \mathrm{H}$

** 正会員 津山工業高等専門学校（津山市沿 624-1)

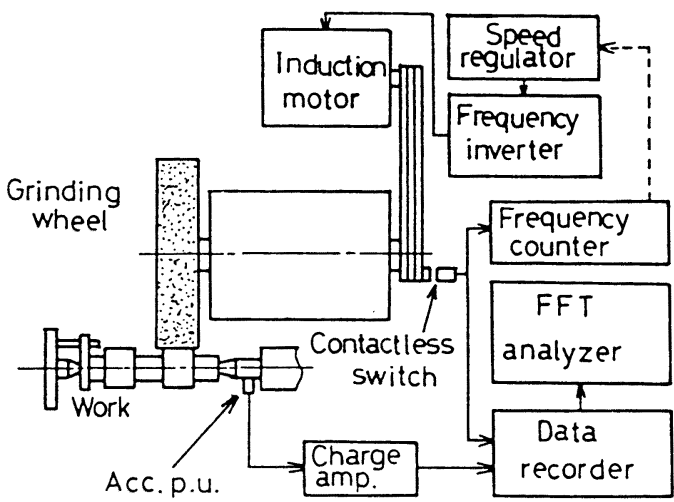

Fig. 1 Illustration of the grinding test setup

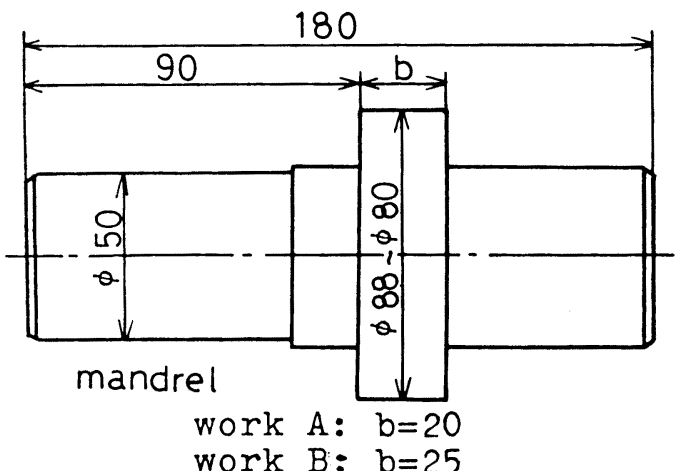

work $B: b=25$

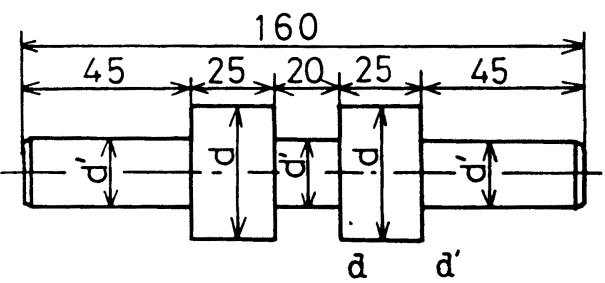

work C: $50 \quad 40$

work D: $32 \quad 27$

work E: 5830

Fig. 2 Work shapes and sizes used for grinding experiments 

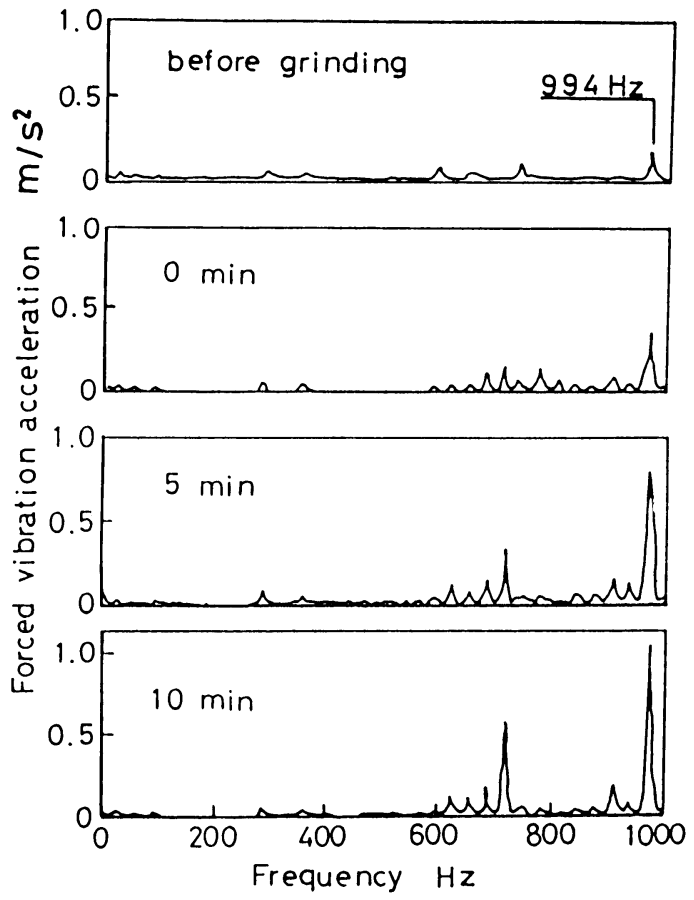

Fig. 3 Time dependent variation of the forced vibration acceleration $(994 \mathrm{~Hz})$ (work B)

工 作 物: A, B, C S 45 C 焼入れ材 $(\mathrm{HRC}=30)$

D, E S 45 Cな材

各形状は図 1 に示す.

砥 石:WA $60 \mathrm{KV} 25(\phi 305 \mathrm{~mm} \times 32 \mathrm{~mm})$

砥石回転数：32.0土0.05 rps, $31.6 \pm 0.05 \mathrm{rps}$

研削条件：工作物回転数 $66.4 \mathrm{rpm}$ (空転時) 切込2送り速度 $1 \mu \mathrm{m} / \mathrm{rev}$ of work

研 削 液：ソリューション型水溶性研削液

\section{3. 強制振動の観察}

\section{1 強制振動の振動源と周波数の決定}

この円筒研削盤で問題となる強制振動の周波数は，液体注入 式オートバランサ ${ }^{4)}$ で十分にバランスをとった (FFT 解析器 による観測では砥石台の振動振幅は $0.02 \mu \mathrm{m}$ 以下である）砥

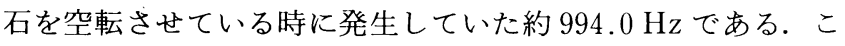
の周波数の振動は, 砥石回転を止めて砥石軸用流体軸受に油圧 を供給するギヤポンプだけが作動している時にも発生している ことから, ギヤポンプが振動源であることがわかった。

\section{2 強制振動増大の様子}

空転中から存在する強制振動は, 通常は研削が始まってもそ のままのレベルを保つと考兄られるが，工作物の形状，寸法に よっては図 3 , 図 4 に示すように研削開始直後から激しく増大 していく場合がある. 増大の様子をFFT 解析器で観測する と, 問題の周波数のスペクトルは短時間の間に大きくなったり 小さくなったりを繰り返しながら，次第にそのレベルを上げて いく．そして工作物 B では研削開始後 12〜13 min で，また工 作物 A では 15 min 位でピークに達し, その後ほぼ同じレベル の振動を維持する.これに対して工作物 C, E では研削時間の 経過に伴ら増大はわずかであり，工作物 Dについては全く増 大は見られない。

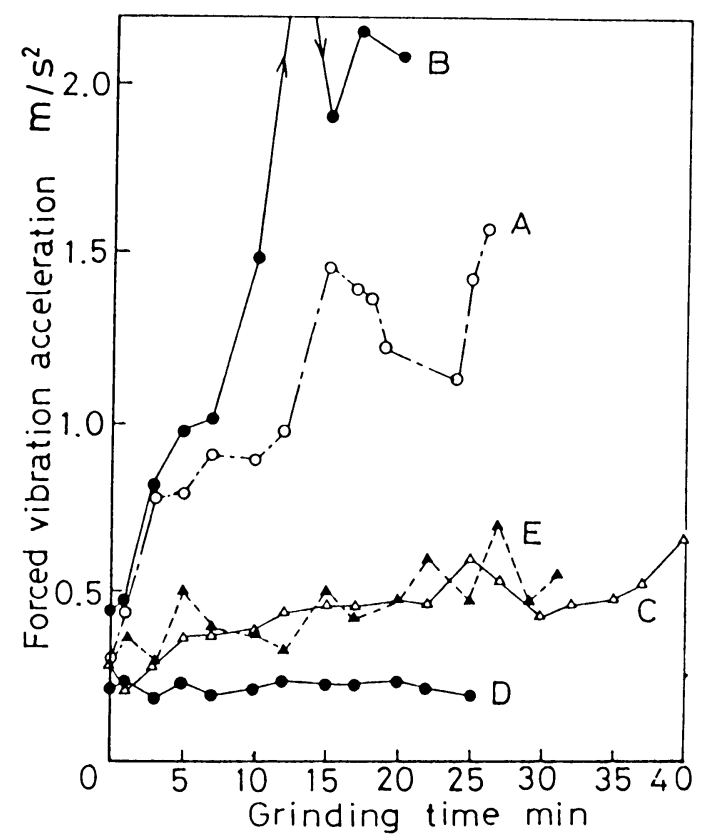

Fig. 4 Time dependent variation of the forced vibration acceleration $(99.4 \mathrm{H} \%)$ in each work

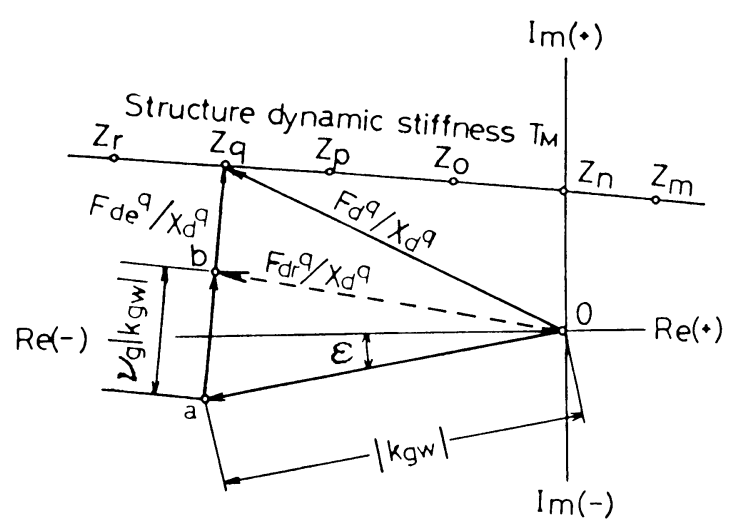

Fig. 5 Cirinding dynamics model illustrated on the stiffness vector diagram

\section{4. 理論モデルによる考察}

\section{1 理論モデルの概要}

著者らがこれまでに提案した理論モデルを用いて，先に述べ た現象を説明するため，その理論の概要を述べる.

研削中の拢動の発生には次の3つの垷象が重要である。（1） 砥不回転に伴与強制的外乱要财（研们の動的アンバランスや硬 さむら）によって生じ, 多数の高調波成分 $F_{\mathrm{de}}{ }^{l}, F_{\mathrm{de}}{ }^{m}, F_{\mathrm{de}}{ }^{n}$, … からなる研削抵抗の変動，（2）静的研削抵抗の大きさに連

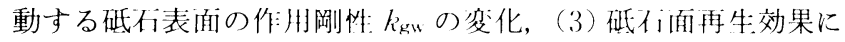
より形成された砥不表面のらねりの起伏の，䂣不・丁.作物間の 相対振動振幅 $X_{\mathrm{d}}$ に対与る割合を表す砥们面転军係数 $\nu_{\mathrm{g}}$.

動剛性ベクトル線汹にそのしくみを表すと，図５:部の曲線 $\mathrm{T}_{\mathrm{M}}$ は砥石と工作物が接触していないときの機械構造系の動剛 性ベクトル軌跡である. $\mathrm{T}_{\mathrm{M}}$ 線 1 に亦した点 $Z_{m}, Z_{n}, Z_{0}, \cdots$ は周 波数を表して拉り，それらは砥不吅転夙波数の整数倍の檤であ る.さて研削が始まった時の状洗は図の点aのような $\operatorname{Re}($ 軸下方の位置で表すことができる。すなわち機械構造に作用す る変動力 $F_{\mathrm{d}}$ は砥不问転に伴ら強制的な変動力 $F_{\mathrm{de}}$ と, 工作物 抢よび砥不面再生効果などの過程によって生じる変動力 $F_{\mathrm{dr}}$ の 
ベクトル利であり

$$
F_{\mathrm{d}}=F_{\mathrm{dr}}+F_{\mathrm{de}}
$$

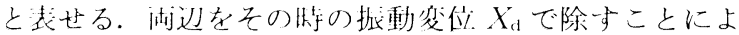

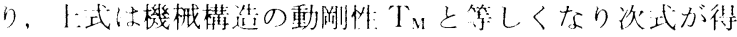
られる。

$$
T_{\mathrm{M}}=\begin{aligned}
& F_{\mathrm{d}} \\
& \mathrm{X}_{\mathrm{d}}
\end{aligned}=\begin{aligned}
& F_{\mathrm{dr}} \\
& X_{\mathrm{d}}
\end{aligned}+\begin{aligned}
& F_{\mathrm{de}} \\
& X_{\mathrm{d}}
\end{aligned}
$$

この咸倸は，生じている坡動の齐阔㳊数成分について成

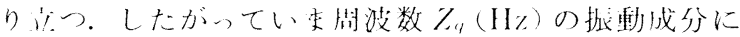
符肘与扎ば

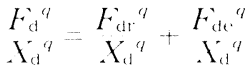

となり，四に亦尗ベクトル

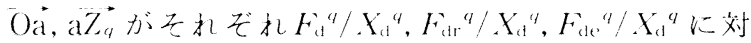
纯与る。元して

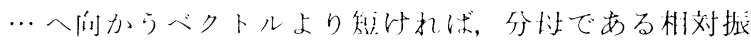

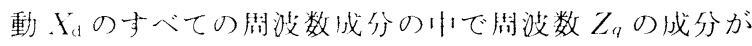
最专大きいこと去小している。

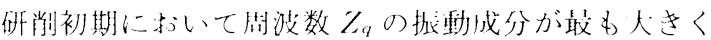

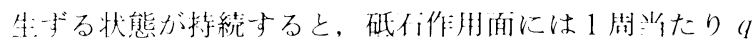

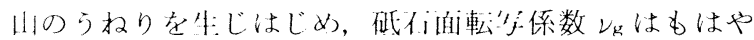

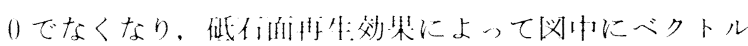

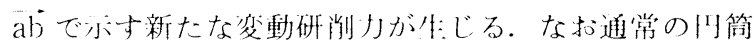

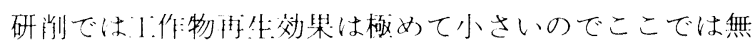

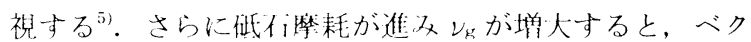

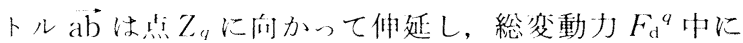

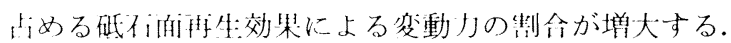
その結榡ベクトルはbZ゙のように短くなり，砥们川転 に伴与強制的变動研测抵抗 $F$ d ${ }^{4}$ の大きさが変わらない

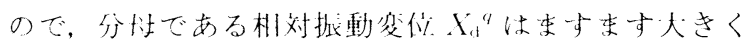
なっていく.

\section{2 動剛性べクトル線図による解析}

インパルス代答武験によって求めた，碈们とに作物が 接触していない時の機械槿造のコンプライアンス伝澾関

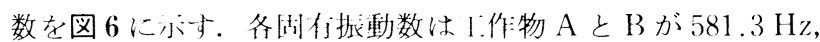
Cが7(00.0 Hz, I) は993.7 H\%, Eが $731.3 \mathrm{~Hz}$ で, 「.作物 D の塕命，問題となった外乱の衙波数とほとんど・致している.

コンプライアンス伀澾関数にそれぞれの位相情報を組み合わ せて求めた動剛珄:ベクトル線闵を図 7 に示す。眼には問題と なった約 $994 \mathrm{H} z$ の外来拔動の增大が最も激しかった厂作物 B のベクトル軌跡の活注全体を亦して打り，他の工作物について

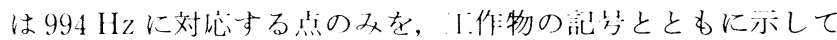
いる。図に打いて，研削初期の状洗は後に述べる专験の結果か ら推定すると，点aのような位置で表すことが出来る。すな わちベクトルのa゙の铱さがインナモジュレーションを表し，そ の虚数部効果によって生ずる減咬効果 ${ }^{(6)}$ のため, $\operatorname{Re}(-)$ 軸よ り角度 の増大が最も激しかった丁作物 Bについて見てみると，ベク トル線ト:の $994 \mathrm{~Hz}$ の㸃が，点 a に非常に近いことがわかる. この周波数は砥们川転周波数のほとんど31 倍周波数であり， 理論モデルで述べたように $F_{\mathrm{de}}{ }^{31} / X_{\mathrm{d}}{ }^{31}$ に対応するべクトルが他 の周波数の点に対するものより短いため, 研削初期から 994 $\mathrm{H} z$ の振動が顕著に垷れるものと理解される. そして研削系の 外から入った $994 \mathrm{~Hz}$ の外乱が同位相で入ってきたため, 励振 作用を及汪し，研削初期から $994 \mathrm{~Hz}$ の振動が激しく増大して

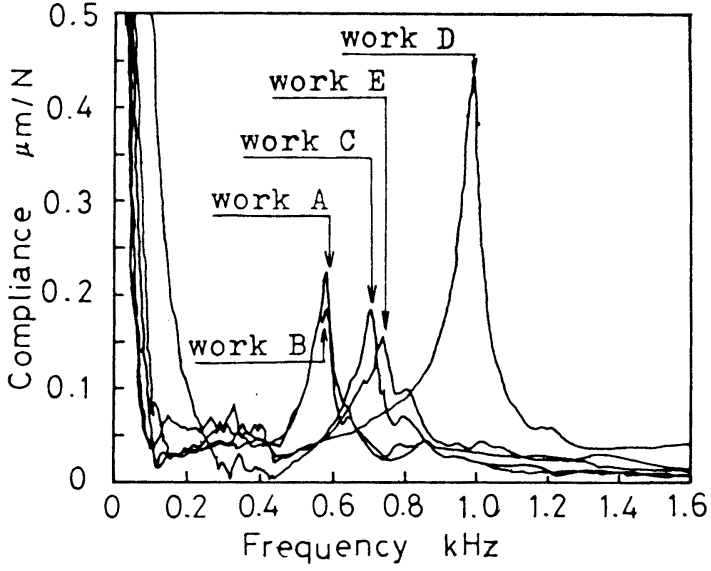

Fig. 6 Dynamic compliance of each work in noncontact with the wheel

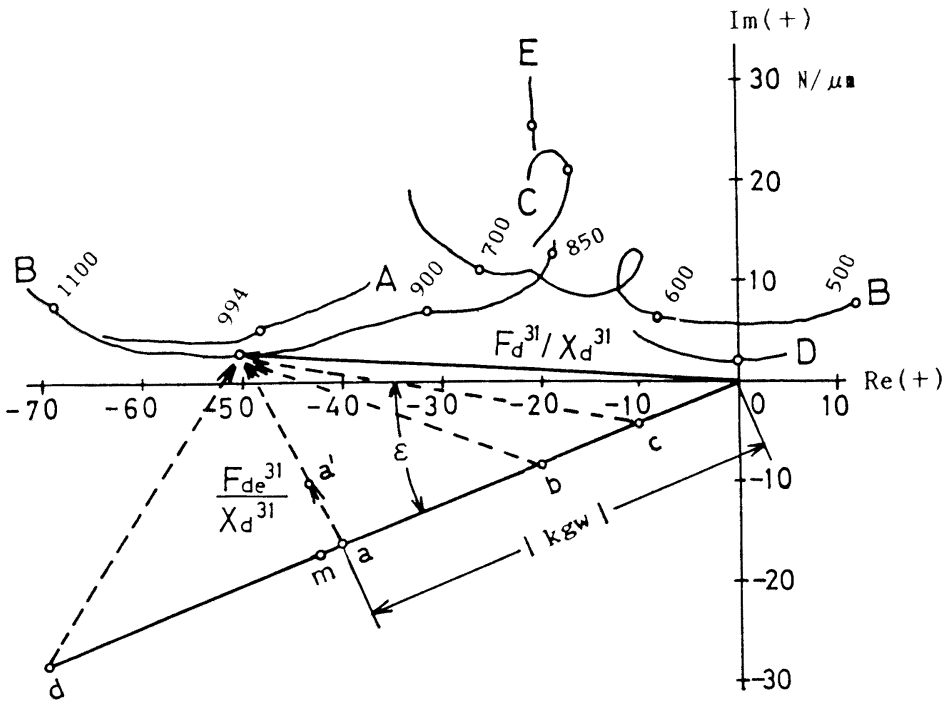

Fig. 7 Stiffness vector diagram of grinding dynamics explaining the amplified vibration at $994 \mathrm{~Hz}$

いったものと考えられる. 研削の進行につれ砥石面再生効果に よって a 点は a'点へと移動していき, $994 \mathrm{~Hz}$ の振動はますま す大きくなっていくことになる.

工作物 A については, ベクトル線は工作物 Bより少し上方

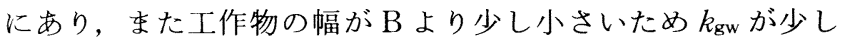
小さくはなるが，B の場合とほぼ同様に考えることがでさる. 工作物 C, Eについてはベクトル線はかなり上方にあり，994 $\mathrm{Hz}$ の点も $\mathrm{a}$ 点からはるかに離れているため, $994 \mathrm{~Hz}$ の振動 は顕著にならない，しかし工作物 Dについては，研削幅を極 端に小さくすると $k_{\mathrm{gw}}$ が小さくなり，したがって $F_{\mathrm{de}}{ }^{31} / X_{\mathrm{d}}{ }^{31}$ が 小さくなって振動変位振幅 $X_{\mathrm{d}}{ }^{31}$ が大きくなる可能性がある. このことを確かめた実験結果を図 8 に示す. 図から研削幅を $1 / 4,1 / 8,1 / 25$ と小さくしても $994 \mathrm{~Hz}$ の振動振幅の増大は生 じていないことがわかる．これは研削幅が小さくなるにつれて $F_{\mathrm{de}}{ }^{31}$ も小さくなり， $X_{\mathrm{d}}{ }^{31}$ の増大が観測しにくくなってしまう ためと考兄られる. したがって，D点のよらな特性を持つ工作 物を研削する場合，その外乱振動の影響は実用上差し支えな く, 外乱振動が有害となるのは, A, B のように O 点から $\operatorname{Re}$ (一)方向に隔たった所で動剛性べクトル軌跡が $\operatorname{Re}($-) 軸に接 近する場合であることがわかった.

\section{3 振動増大の抑制方法}




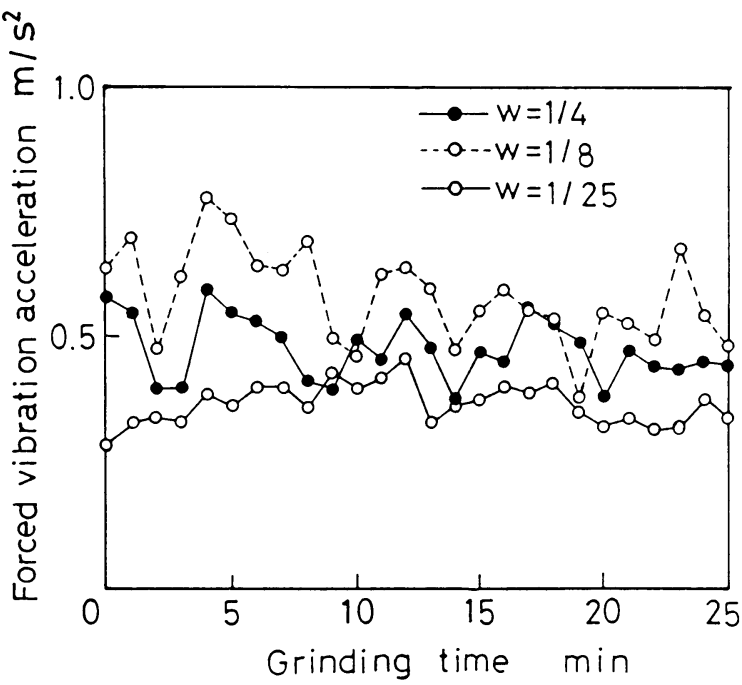

Fig. 8 Variation of the forced vibration when grinding the work $\mathrm{D}$ with small grinding width

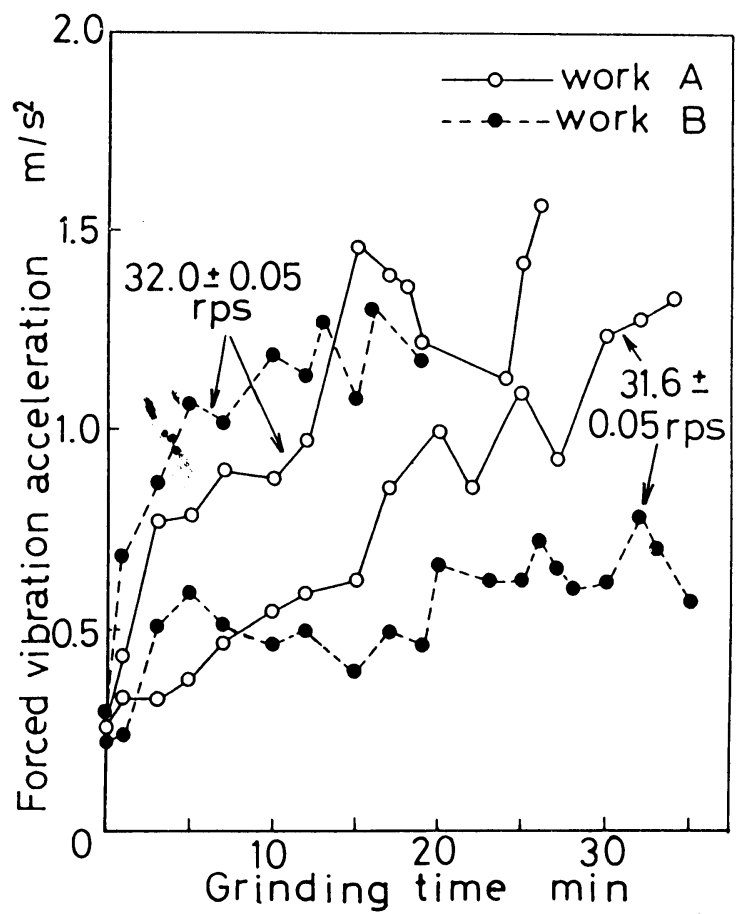

Fig. 9 Variation of the amplified forced vibration by changing the wheel speed slightly

これまでの考察から, 問題となった外乱の周波数の振動増大 を抑制するためには二つの方法が考兄られる。すなわち

（1）砥石回転数をわずか変化させ， $994 \mathrm{~Hz}$ が砥石回転周波 数の整数倍に近くならないようにして，外乱による励振作 用を防ぐ。

（2）研削幅を変兄るなどして作用剛性 $k_{\mathrm{gw}}$ の大きさを変え， 図 7 の a 点の位置が b, c あるいは d 点に移動するように し, ベクトル線上の $994 \mathrm{~Hz}$ の点から遠ざかるよらにす る.

図9 は砥石回転数を $32.0 \pm 0.05 \mathrm{rps}$ から $31.6 \pm 0.05 \mathrm{rps}$ と わずか変化させた時の結果で, 前者の約 31.0 倍, 後者の約 31.5 倍が外乱の周波数 $994 \mathrm{~Hz}$ である. 図から工作物 A, B と もに十分とはいえないがかなりの抑制効果が認められる.

図 10 は砥石回転数 $(32.0 \pm 0.05 \mathrm{rps})$ は変えず, 工作物の

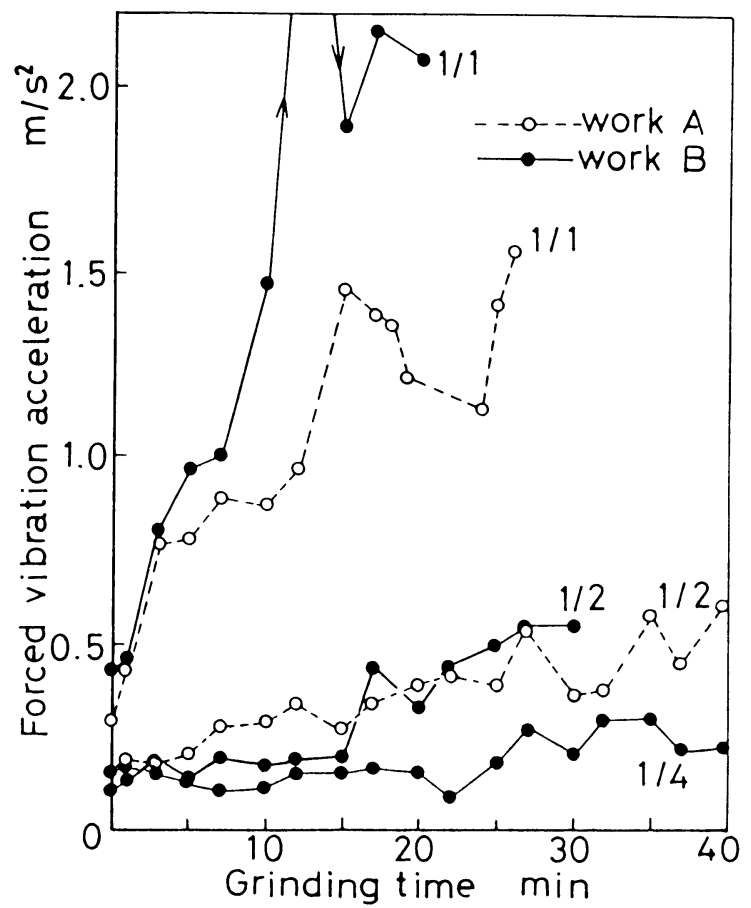

Fig. 10 Variation of the amplified forced vibration by changing the grinding width

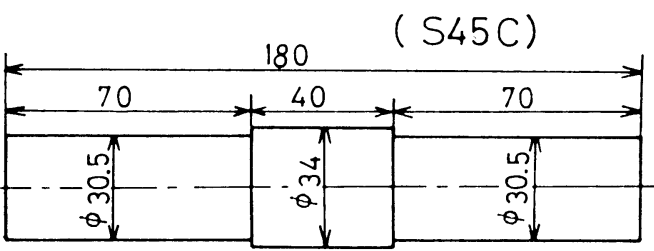

$\operatorname{Im}(+)$

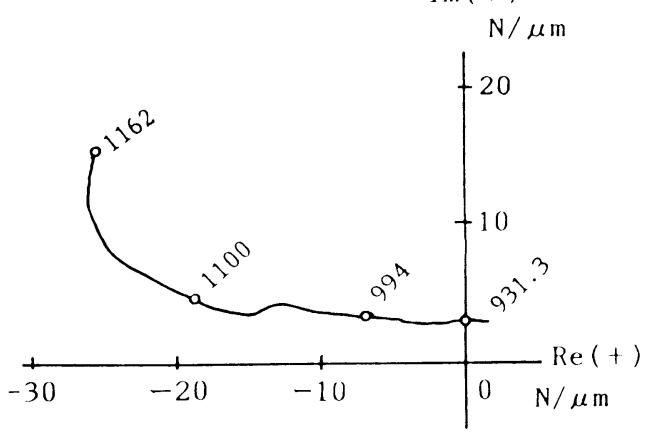

Fig. 11 Work shape and its stiffness vector diagram used for the grinding test changing the grinding width very widely

研削幅を変化させることによって作用剛性 $k_{\mathrm{gw}}$ を大きく変えて 行った実験結果であり，抑制効果が確或に現れていることがわ かる．研削幅を $1 / 2 ， 1 / 4$ にするということは，図7で a 点が ほぼb, c 点に移動することであり, 前述の理由から $X_{\mathrm{d}}^{31}$ の振 動振幅は小さくなる．末た研削幅を大きく増やして a 点をd 点あたりに移動させることも有効と考兄られる。このことを確 かめるため図 11 に示すよらな動特性を持つ工作物を作製し， 研削幅を大さく変化させた実験を行った。この時, $994 \mathrm{~Hz}$ の 外乱振動の増大を最も速やかにする研削幅は $11.5 \mathrm{~mm}$ であり, この值を中心にして研削幅を増减した，図 12 の（a)，(b)に実 験結果を示す．研削幅を減少させた時はこれまでと同じ結果を 示して扣り, 逆に増大させた場合も, 研削幅の増大とともに外 乱振動の増大は小さくなっていることがわかる. 


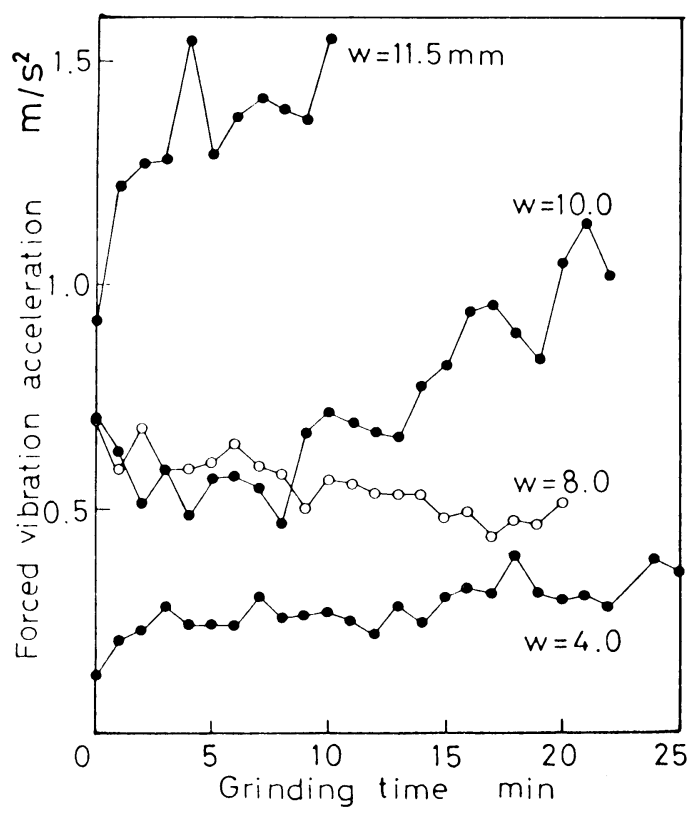

( a )

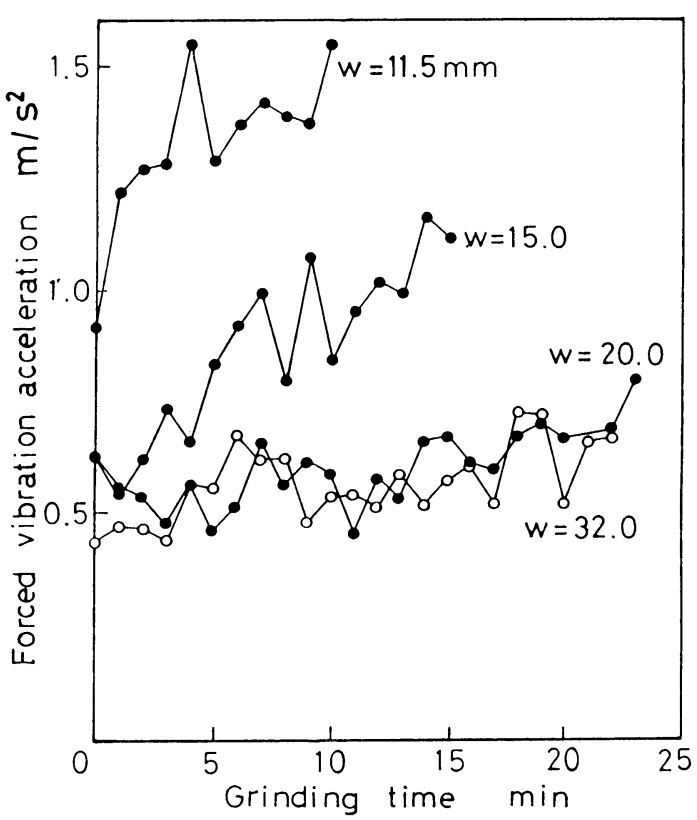

( b )

Fig. 12 Variation of the amplified forced vibration by decreasing and increasing the grinding width ( $w$ ) when grinding the work having the dynamic stiffness in Fig. 11

k 变変化させる別のう法として，切込及送り速度を変える ことも考えられる．１:作物 Bを朋いて，それを $2 \mu \mathrm{m} / \mathrm{rev}, 3$ $\mu \mathrm{m} / \mathrm{rev}$ と変化させて研澈を行ったところ, $994 \mathrm{~Hz}$ の振動増

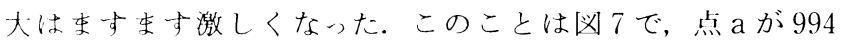
$\mathrm{Hz}$ の点からの最短趾離の㷛 $\mathrm{m}$ に近づく方向に移動したと考学 ることができ，逆に䈍aの概略の位㯰を推起できた。

\section{5. 結 論}

ある研㴥盤においいてギヤポンブから発化:する強制拨動が研削 中に増幅される現像を，さきに提案した動岡件べクトル線図を 用いる理論モデルに当てはめて解析した。 その結果, ベクトル 線図が問題の外乱振動の閏波数に损いて，（点から $\operatorname{Re}(-)$ 方 向に隔たったところで $\operatorname{Re}($ 一) 軸に接近する場合には増大が生 じることがあり，邀く離れている埸令には增幅現象は生じない ことがわかった。

この研究により，研们叮転数に间期しない外乱振動がある場 合に，それが研削中に増幅されて仯售な拢動となる機構とその 条件が明らかとなった。その埸命の拔動增大の抑制方法として
（1）砥石回転周波数は, その整数倍が外乱の振動周波数に 一致，もしくは近くにならないようにする.

（2）研削幅を $1 / 2 ， 1 / 4$ あるいは 2 倍などにして，接触剛性 を大きく変える.

の 2 つがあるが，（2）の方法が効果的である.

本研究を遂行するにあたり, 貴重な助言を頂きました豊橋技 術科学大学星鐵太郎教授に深く感謝致します。

$$
\text { 参 考 文 献 }
$$

1) 星 鐵太郎, 三井 聡, 堀内 幸: 円筒プランジ研削に拈ける振動 抑制の一方法, 精密工学会誌, 53, 6 (1987) 940.

2) 劉 錫強, 中野嘉邦, 加藤秀雄: 平面研削に打ける油圧の脈動に起 因するびびりマークの抑制, 精密工学会誌, 55, 3 (1989) 514.

3）星 鉄太郎，高本洋祐：円筒プランジ研削に打ける振動の発生機構, 精密機械, 49, 12 (1983) 1680.

4）堀内 幸, 小島英男：新型の液体注入式研削砥石オートバランサ, 精密工学会誌, 52,4（1986）713.

5）例党ば，砥粒加工研究会編：䃨粒加工技術便覧，日刊工業新聞社， (1955), 843.

6）星 鐵太郎：びびり現象, 工業調査会, (1977） 46 . 